\title{
Correction to: Culture of mesenchymal stem cells derived from equine synovial membrane in alginate hydrogel microcapsules
}

Vitor Hugo Santos ${ }^{1}$, João Pedro Hübbe Pfeifer ${ }^{1}$, Jaqueline Brandão de Souza ${ }^{1}$, Betsabéia Heloisa Gentilha Milani ${ }^{\text {, }}$ Rogério Antonio de Oliveira ${ }^{2}$, Marjorie Golim Assis ${ }^{3}$, Elenice Deffune ${ }^{4}$, Andrei Moroz ${ }^{5}$ and Ana Liz Garcia Alves ${ }^{1 *}$

\section{Correction}

The original article [1] contained a minor error regarding the mean diameter of the alginate microcapsules described in relation to Fig. 4 in the Results section. The microcapsules had an actual mean diameter of $3000 \mu \mathrm{m}$ instead of $1000 \mu \mathrm{m}$ as mistakenly mentioned in the original article.

\begin{abstract}
Author details
${ }^{1}$ Department of Veterinary Surgery and Anesthesiology, University of Veterinary Medicine and Animal Science UNESP, District of Rubião Júnior, s / n, Botucatu,

São Paulo, Brazil. ${ }^{2}$ Departament of Statistics, Institute of Biosciences, UNESP, District of Rubião Júnior, s / n, Botucatu, SP, Brazil. ${ }^{3}$ Departament of Graduate Program in Research and Development, Medical Biotechnology, UNESP, Blood Centre Division, District of Rubião Júnior, s / n, Botucatu, SP, Brazil.

${ }^{4}$ Departament of Urology, Blood Centre Division - Laboratory of Cellular Engineering, University of Medicine, UNESP, District of Rubião Junior s / $n$, Botucatu, SP, Brazil. ${ }^{5}$ Departament of Bioprocesses and Biotechnology, FCFAR UNESP, Rodovia Araraquara Jaú, KM 01, São Paulo, Brazil.
\end{abstract}

Received: 27 May 2018 Revised: 29 August 2018 Accepted: 29 August 2018 Published online: 07 October 2018

\section{Reference}

1. Santos VH, et al. Culture of mesenchymal stem cells derived from equine synovial membrane in alginate hydrogel microcapsules. Stem Cell Res Ther. 2018;14:114. https://doi.org/10.1186/s12917-018-1425-0

\footnotetext{
* Correspondence: anaalves@fmvz.unesp.br

'Department of Veterinary Surgery and Anesthesiology, University of Veterinary Medicine and Animal Science UNESP, District of Rubião Júnior, s / n, Botucatu, São Paulo, Brazil
} 